\title{
Immaterial Dimensions of the Right to the City: The Case of Istanbul's Derbent Neighborhood in the Urban Transformation Process
}

\section{Kent Hakkının Maddi Olmayan Boyutları: Kentsel Dönüşüm Sürecindeki Istanbul Derbent Mahallesi Örneği}

\author{
Gizem Aksümer, Hakan Yücel \\ ${ }^{1}$ Department of Urban and Regional Planning, Mimar Sinan Fine Arts University, Istanbul \\ ${ }^{2}$ Department of Political Sciences, Galatasaray University, Istanbul
}

\begin{abstract}
The main objective of this article was to discuss the concept of the right to the city using the example of a gecekondu settlement, sometimes referred to as a squatters' neighborhood or a slum, that is part of a transformation project. The article primarily emphasizes the importance of the immaterial and empirical dimensions of the concept of the right to the city. Within this context, the theoretical part of the article is based on the Lefebvrian concept of the right to the city, which may be explained as the right to live anywhere one wishes to live and/or to decide one's own future.

Starting from this point, a study of Istanbul's Derbent neighborhood, a gecekondu neighborhood undergoing an urban transformation process, was conducted. The goal was to seek tangible information on how the inhabitants of the gecekondu neighborhood were currently living and how they wish to live in the future. Additionally, how the urban transformation process is progressing in the opposite direction for this area is illustrated. The findings revealed that Gecekondu inhabitants have a strong sentiment of belonging to the place. They are emotionally attached to the location and to their neighbors. These emotional, intangible, and invisible dimensions of place attachment are very important components of the right to the city.

Keywords: Right to the city; urban transformation; Istanbul; gecekondu; Derbent; neighborhood.
\end{abstract}

ÖZ

Bu makalenin temel amacı, kent hakkı kavramını kentsel dönüşüm tehdidi altındaki bir gecekondu mahallesi üzerinden tartışmaktır. Makale, temel olarak kavramın materyal olmayan, ampirik boyutlarının altını çizmektedir. Bu bağlam içinde makalenin teorik kısmında Lefebvre'in ortaya attığı, bireyin istediği yerde yaşama ve kendi geleceğine karar verme hakkı olarak da anlaşılabilecek kent hakkı kavramı tartışılacaktır.

Bu noktadan hareketle, kentsel dönüşüm tehdidini deneyimleyen İstanbul Derbent mahallesinde bir araştırma yapılmıştır. Bundaki amacımız, gecekondu mahallesindeki insanların nasıl yaşadıklarını ve gelecekte nasıl yaşamak istediklerini araştırmaktı. Buna ek olarak bu makale, mevcut kentsel dönüşüm ihtimalinin mahalledekilerin taleplerinin aksi yönde işlediğini göstermeyi amaçlamaktadır. Dolayısıyla makale iki temel izleğe sahiptir. Öncelikle, Derbent mahallesinde yaşayanların nasıl bir hayat tarzına sahip olduğu anlaşılmaya çalışılacak, ikinci olarak mahalle sakinlerin gelecekte nasıl bir mahalle hayal ettikleri aktarılacaktır. Bulgular, mahalle sakinlerinin çok güçlü bir mekansal aidiyet hissine sahip olduklarını göstermektedir. Saha araştırması tespitlerimize göre Mahalle sakinleri mekâna ve komşularına duygusal bağlıık içindeler. Biz de bu makalede, mekâna bağlıı̆̆ın bu duygusal boyutlarının kent hakkının çok önemli birer parçası olduğunu tartışmaya açıyoruz.

Anahtar sözcükler: Kent hakkı, kentsel dönüşüm, İstanbul, gecekondu, Derbent, mahalle.

\footnotetext{
I Gecekondu is the common and particular name of informally and autonomously built houses in Turkey. These buildings started to be built in the 50s and they are comparable to favelas in Brazil or bidonvilles in France; but these structures create neighbourhoods and even big townships. In the 2000s, there are also many gecekondu neighbourhoods all over Turkey, Gecekondu settlements are also known to build a kind of "urban social movement" in cities. For further details: ERDER Sema, "Kentsel Gelişme ve Kentsel Hareketler: Gecekondu Hareketler", Kent, Yerel Siyaset ve Demokrasi, İstanbul, Demokrasi Kitaplığı, 1998, s.293-309. Jean François Pérouse, "Les tribulations du terme de gecekondu (I947 - 2004): une lente perte de substance. Pour une clarification terminologique." European Journal of Turkish Studies, sayı I- Gecekondu, Web: http://www.ejts.org/documentI I 7.htmlart
} 


\section{Introduction}

This article focuses on gecekondu neighbourhoods and aims to understand the meaning of the right to the city for these settlements. The main purpose of the article is to elaborate the immaterial dimensions of the right to the city, figure out how the inhabitants of this gecekondu neighbourhood live and how they wish to live in the future. Immaterial dimensions emphasize the importance of the moral components of the right to the city such as the sentiment of belonging to the place of living, ability of establishing solidarity and networks, having close social relations or even the sole enjoyment of the space. This article underlines such non-productive and mostly forgotten dimensions of the concept and claims that they are very important in intervention, design or renewal of urban space regarding the right to the city. One of the main arguments is that the necessity of the right to the city for citizens cannot be limited only to economic and political dimensions. Attachment to the place or the emotional flows running through the neighbourhood; create the most important inputs to the search for the right to the city. The right to the city is connected to the sentiment of belonging, or place attachment. Secondly, focusing on the situation in a gecekondu neighbourhood experiencing an urban transformation process, this article will try to show that even if the urban transformation project offers apartments for most citizens, it cannot meet immaterial needs in terms of place attachment or social relations.

This article will emphasize two aspects of the issue. On one hand, we reveal what kind of urban space gecekondu residents are expecting to live in. On the other hand, we introduce an analysis of the urban transformation project by looking for the aspects of the project that are perturbing for gecekondu inhabitants. This analysis will advise us to watch the operational process of urban transformation on a gecekondu neighbourhood scale and we will try to search for the right to the city in this process. We will especially indicate the components constituting the right to the city in the investigated neighbourhood and figure out why the new project cannot put the right to the city into practice.

The findings are from field research conducted within the scope of a TUBITAK ${ }^{2}$ project, which was carried out in 2013 in the Derbent gecekondu neighbourhood in the district of Sariyer in Istanbul, Turkey. After the completion of the project, we have continued to monitor the process in the district until today. While searching for the components of the right to the city during an urban transformation process, we focus on the daily practices of neighbourhood residents. The expectations of inhabitants and the life style provided in the urban project were studied within the scope of the article.
In the following sections, we investigate two topics: firstly, we try to explore the citizens' current daily life style, and secondly, the expectations of the gecekondu residents for the future. These two topics guide us to find out what the components of the concept of the right to the city for this specific neighbourhood might be. The first section of the article discusses the right to the city. We review especially the Lefebvrian meaning of the concept and important topics; which are emphasized by academics working on the concept. In the second section, we elaborate the field research and discuss our findings under 4 sub-sections. Firstly, to facilitate the progress of the article, the urban transformation process in Istanbul is described, focusing on the case of Derbent. The three following sub-sections analyse the design process of this old gecekondu neighbourhood, the solidarity networks established in more than 50 years, institutionalisation of these solidarity networks, and discuss their meaning in the search for the right to the city. Besides, these three subsections will shed light on the immaterial dimensions of the right to the city.

\section{Theory: Right to the City}

In his book "The Production of Space", Lefebvre (I99I, p. 85) claims that space is never produced in the sense that a kilogram of sugar is produced. It is not a simple object but an outcome of a set of operations. Space is conceived as transformed into a 'lived experience' by a social 'subject'. It is a product of social relations (199I: 85) and "a precondition and result of social superstructures". According to him (1991: 85), space can contain all senses and all bodies: "Though a product is to be used, consumed, it is also a means of production; it determines networks of exchange, flows of raw materials, energy fashion space and are determined by it".

Here, we need to emphasise the conceptual triad of Lefebvre (199I: 33) including spatial practice, representations of space, and representational space. Spatial practice indicates the society's relationships to the space. Lefebvre claims (199I: 38): "The spatial practice of a society secretes that society's space; it propounds and presupposes it, in a dialectical interaction; it produces it slowly and surely as it masters and appropriates it." Representation of space refers to the ideas, codes and forms, which are tied to the space. All ideas like plans and cartographies are included in this conceptual space. Lefebvre says (1991: 38): "This is the dominant space in any society (or mode of production)". Representational space is the symbolic side of the space linked to the underground side of the society (Lefebvre, 1991: 39): "It is space as directly lived through its associated images and symbols and hence the space of 'inhabitants' and 'users', but also of some artists and perhaps of those such as a few writers and philosophers, who describe and aspire to do no more than describe." Thus, pro- 
duction of space is realised by the combination of these three conceptual production phases; which always work together.

Lefebvre (1996, p. 147) underlines that social needs have anthropological foundations and human beings need to hear, see, taste, touch and bring together these perceptions. He (1996: I58) states, "The right to the city cannot be conceived as a simple visiting right or a return to traditional cities. It can only be formulated as a transformed and renewed right to urban life." On the other hand, Lefebvre (1996: 155) claims that mature urban projects do not concern studies of the existing city and he (1996: 155) claims, "Other than contrary to experience, the forms of space and time will be invented and proposed to praxis." Lefebvre takes space on one hand as a concrete object, and on the other as a concept and experience (Avar, 2009, p. 7). According to Lefebvre (1996), conceptual space, which is produced by architects or planners, creates the main foundations of the capitalist system. Avar expresses (2009: 12) that, in urban projects, concrete space is replaced by conceptual space. In this situation, the project seems to be the reality, but it is only a representation of space.

Considering the trilogy in production of space, Lefebvre (1996) creates the concept of the right to the city. The right to the city not only includes the rights concerning the form of the physical space but it is also combined with urban life with its emotional context, its leisure time possibilities or capacities of encountering. Lefebvre (1996: 158) underlines that "It (the right to the city) can only be formulated as a transformed and renewed right to urban life." Marcuse (2012) interprets this as a cry and a demand.

Accordingly, we may deduce that the right to the city cannot be limited to a housing right or life in a good environment, but it must include the right to self-governance and the right to preferences for a life style as well. Even if Lefebvre opens a comprehensive debate about different aspects of the concept, the current literature is often limited. This concept is mostly declared as a housing right (Budds, 2015; Langegger, 2016) or a right ensuring participation (Pierce, Williams, \& Martin, 2016; Mark;. Purcell, 2002; Mark; Purcell, 2003) in urban government. Most of these articles underline the economic and quantitative part of the right to the city.

Every researcher working on the right to the city tries to focus on one part of the concept and puts another perspective into Lefebvre's discussion. Purcell (2002: 100) indicates that the discussion by Lefebvre is a more radical and open-ended view than the current literature. Lefebvre does not suggest an alternate urban life but emphasizes unifying every stakeholder to scream for the right to the city and hopes for awakening the working class for collaboration with white-collar people.
On the other hand, Harvey (2000, 2008), whose arguments on the right to the city are very frequently used in parallel with Lefebvre's, takes the right to the city as a tool for criticising neoliberal urban development. Furthermore, he (2000) claims that Lefebvre leaves the concept of the right to the city undefined and tries to find a way and create "spaces of hope" departing from Lefebvre's starting point. McCann (2002, p. 78), as a brief overview of the concept, claims that Harvey suggests a new utopianism in urban political studies. Additionally, he associates the right to the city with citizenship and brings us to public participation during the planning process.

Margrit Mayer (201 I: 154), in her article making derivations from Lefebvre's ideas, states that the right to the city is a type of a right of redistribution and it is an adversary demand instead of being a legal right. Likewise, this article considers Mayer's case as resistance to being besieged by urban transformation and struggle to protect spatial solidarity networks.

The right to the city may be depicted as the right to access all daily life habits, humanitarian needs and life style preferences. Within this context, the urban space, which is meant to describe the right to the city, is not a limitable or measurable space but a space that can be senced and experienced. Thus, the right to the city does not only mean access to urban services or living "comfortably" within the city, but it can also be described as a humane project facilitated by urban residents who experience the city individually and interact with each other in a cooperative and emotional form (Purcell, 2009). Looking from this perspective, De Souza (20II) argues that many authors have considered the right to the city in a narrow scope and advocates describing it with multiple definitions. De Souza states that, on a humanitarian scale, houses that can be paid for, policies that protect the environment, and existence of a participatory democratic system are considered as adequate by many civil society organisations to build "the right to the city", but he criticises this and claims that this does not match with the definition by Lefebvre (De Souza, 201 I: 316). In compliance with this, Harvey does not define the right to the city solely as a freedom to access the resources of the city. On the contrary, he defines it as a right to change the city and the self (Harvey, 2008). We may also refer to geographers criticising the overuse of the concept of the right to the city. Attoh (20II) argues that it is a waste of time to define what a right to the city is. Instead, he suggests that scholars working on the right to the city should focus on rights and try to institutionalise the main rights for the citizens.

We may analyse the discussions on the right to the city in three categories. The first group (Balzarini, 2015; Harvey, 2000, 2008; Mitchell, 2003) takes the concept of the right to the city as a tool for criticising neoliberal urban development. 
Numerous geographers in the second group have emphasized that self-expression and urban social movements might have a big impact on urbanisation processes (Bayat, 2010; D. Davis, Moore, Wright, \& Zykofsky, 20I 3; M. Davis, 2006; Friedmann, 1998; Harvey, 2000, 2008) and they may refer to the concept of the right to the city to broaden their perspective. The third group (Langegger, 2016; Masuda, 2016; McCann, 2002; Pierce et al., 2016) criticises the unidentified form of the concept and tries to translate it into urban practice. The majority of these geographers, establish a connection with economic equity. For instance; Buds and Teixeira (2005) mention affordable housing production in Sao Paolo and they emphasise the capacity of this practice to establish the right to the city.

In Turkey, the urban transformation is not used to describe a city which is changed and transformed by the residents, but it is a process of urbanisation reconstructed with top-down policies and in parallel with capital flows. This study does not consider urban transformation with a single meaning or as a singular process. Within this context, this article does not take urban transformation as project-based interventions defined by law but it evaluates urban transformation as a multiagency and multi-form process. Therefore, the study defines the driving force of this process as urban enclosures created through shopping malls, gated community areas, bridges, roads and mega projects (Yalçıntan, Çılgın, \& Çalışkan, 20I2). Besime Sen (2006, p. 183) describes urban transformation projects as a type of a top-down projects that was created without any procedure of participation and defines the case of Turkey as follows: "Gentrification projects aim to prevent spatial and social backwardness, but they increase inequalities. When the areas that serve a large population are transformed with top-down policies and without any level of participation, problems such as 'poverty, crime and unemployment' are not diminished but only transferred to another part of the city, therefore, these problems increase exponentially."

In this sense, being able to live in Istanbul becomes possible only in urban spaces with no alternatives and with the life styles forced by such spaces. In particular, the life style considered appropriate for poor people after urban transformation is living in mass-housing areas as nuclear families. Uncreative children's playgrounds with plastic equipment, landscape arrangements that consist of plants ill-assorted for the climate and the environment, multi-story buildings and "tube lives" of home-work-home forced by urban transformation projects are presented as magical solutions. Kurtuluş (2006) claims that urban transformation is demolition of the modern city myth while Kuyucu and Unsal (2010), regarding one gecekondu neighbourhood case, declare that urban transformation becomes a tool for state-led property transfer. Türkün (20l4), in her edited book, shows us the situation of gecekondu houses under the threat of urban transformation. Türkün et al. (20I4) underline the right to shelter in this kind of projects.

Particularly in Istanbul, most areas where urban transformation projects take place or where the projects of "gentrification" are implemented without using the name of urban transformation are mostly gecekondu neighbourhoods. This necessitated our reading of the effects of urban transformation through these neighbourhoods. Gecekondu neighbourhoods, with vast property problems having affected by urban transformation process, usually oppose to the process and creating associations or cooperatives take the initiative to define their urban space for the future. This encouraged us to shift the focus of this article onto these neighbourhoods. The main target of urban transformation programs that appeared in 2004 and took place in the agendas of central and local governments was "to renew old spaces and diminish the illegal gecekondu settlements” (Sen; \& Doğan, 2010, p. 309). It is possible to say that marginalisation of urban regions by identifying them with crime has a justifying effect for both intervention of security forces (Gönen, 2008) and demolition activities aiming urban transformation. Implementation of urban segregation and urban transformation processes is synchronous. Cleansing of some regions in the city centre and its periphery from poor zones aims to "achieve" spatial and social segregation. ${ }^{3}$ Furthermore, this context includes discourses such as exclusion of unwanted elements or homogenisation of the living spaces of the rich (Pérouse \& Danış, 2005). In addition to this, it is witnessed that institutions such as TOKI ${ }^{4}$ and KIPTAS $^{5}$ facilitate homogenisation of the spaces of the poor, and lead to self-enclosure and periphery settlement. We may observe the segregation and enclosure of the new neighbourhood in the case of the Derbent transformation project.

\section{Field Research}

The basic path of the article is discussing the right to the city through a gecekondu settlement that has not yet experienced urban transformation completely but is under the threat of a transformation project. Within this context, it is important to see as Harvey (2012) said how the right "to live anywhere one wishes to live", "to decide on one's own future", which we consider as the right to the city, is/will be shaped by urban transformation.

3 For social segregation, and the exclusion of gecekondus and people in those regions as "suburb”; please look at: Bali Rifat, Tarz- । Hayattan Life Style' a yeni Seckinler, Yeni mekânlar, Yeni Yasamlar, Istanbul: lletisim Pub.., 3rd edition, 2002.

4 Toplu Konut İdaresi: Mass Housing Administration of Turkey

5 KIPTAŞ was established in the name of IMAR WEIDLEPLAN with a foreign capital partnership in 1987 in order to perform development plans and architectural projects. (Istanbul Konut İmar Plan Sanayi Ticaret Ananim Şirketi: Istanbul Residence Development Plan Industry and Trade Inc.) 
We used a Comparative Qualitative-Quantitative Analysis in our field study, following pilot interviews and analyses in the field along with theoretical reading. It was decided to adapt this mixed methodology into this study, thereby harmonising "the science of discourse" with "the science of numbers" (Albarello, 2007, p. 96). Within the scope of the project, a survey was conducted among 280 people in the Derbent neighbourhood. After this broad survey with 90 questions pondering their perception of the neighbourhood, deducing their life style and the inhabitant's sense of belonging to the neighbourhood, we had three focus group meetings, which were implemented with a women's group, a youth group and a middle-aged residents' group. In addition to data collection in these two sets of work, we repeatedly visited the neighbourhood, the mukhtar, and the neighbourhood association before and after our research project. We were in the field both as academics and activists, we worked together with people searching for a solution for the new situation, and we offered the neighbourhood our professional knowledge. We conducted a 3-4-year-long participatory observation ${ }^{6}$ in the neighbourhood before and during the research. This long-term observation period provided us with preliminary knowledge about the field, social relations in the neighbourhood, different social groups and their different reactions to the project.

To improve the representative power of the survey, we gathered data from our field notes during the participatory observation and we carried out interviews with the neighbourhood association to have a comprehensive view of the specific characteristics of the neighbourhood. We observed that communities coming from the same villages live together in the same street or they stay in the same group of houses in the neighbourhood. This segregation by ethnicity, religious sects (Alevi, Sunnite) or political view was noticeable in the organisation of the space. This comprehensive view of the neighbourhood enabled us to distribute our sample as accurately as we could. Moreover, we made specific effort to make a poll proportionally with men/women, young/middle aged/elderly people (Fig. I).

The decision to form three focus group interviews came right after taking the preliminary results of the survey and the

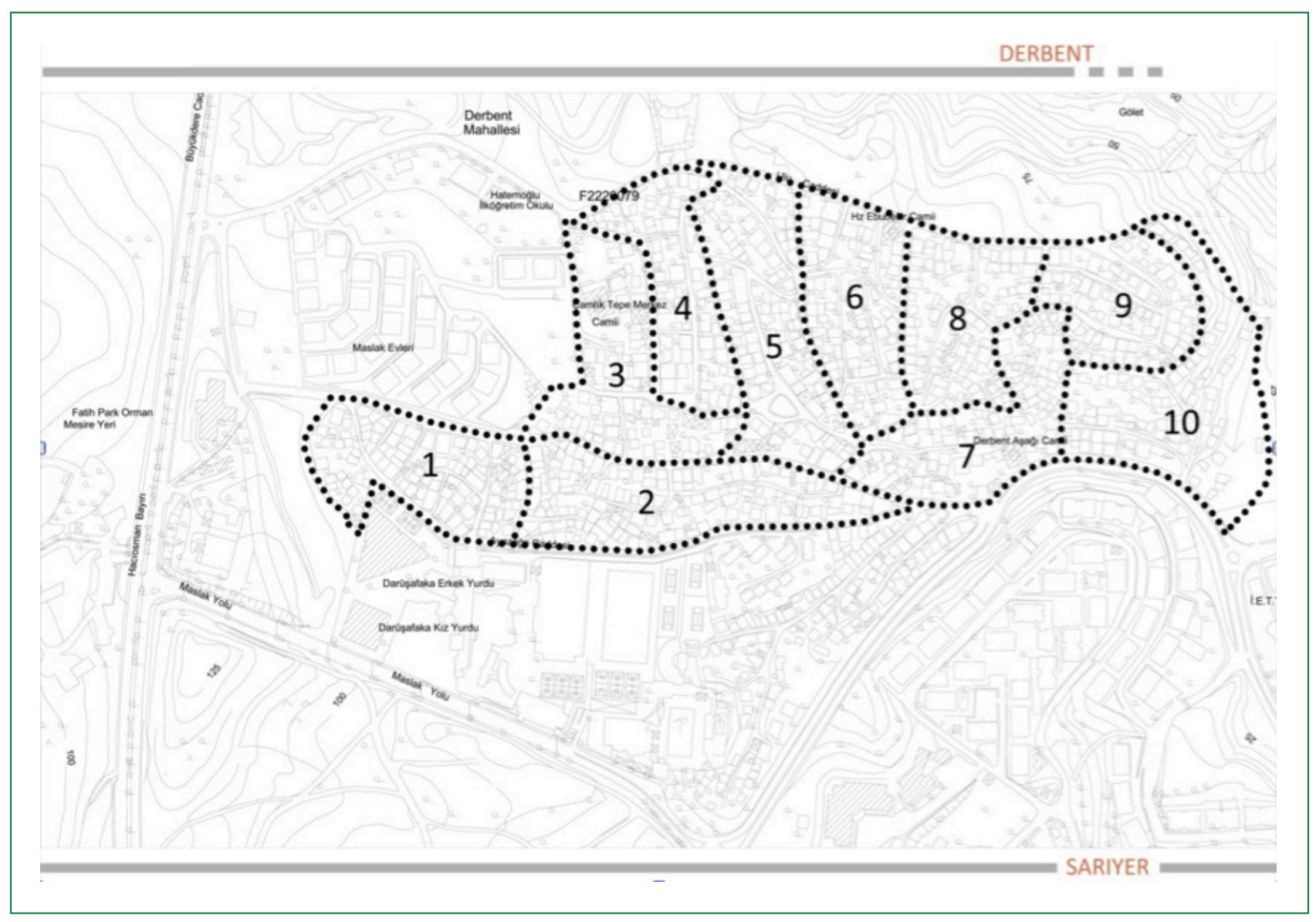

Figure I. Survey zones.

6 We changed the names of the interviewees people to protect their privacy. 
analysis of our field notes during participatory observation. Especially in association meetings or during neighbourhood activities against urban transformation, we usually met middle-aged men and heard mostly their opinions. We confirmed that women and young people could not speak when they were in the presence of older men. For this reason, we needed to have different group discussions to see how differently their decisions about the neighbourhood are taken. Performing a research in a gecekondu neighbourhood under transformation may not provide the opportunity to get in contact with every group, either proponent or opponent. To avoid this problem, we did not use the snowball methodology to find focus group people. We approached the community we had surveyed before and we chose those from different classes and age groups. In every step of the research, especially in thematising the findings, the intense participatory observation provided confidentiality.

\section{Urban Transformation in Derbent}

It is possible to say that closure of factories in our research area and start of the process of building roads-houses-bridges triggered the urban transformation process. The places around the Derbent neighbourhood ${ }^{7}$ have hosted gated communities (MESA housing site) where wealthy people live due to their proximity to the central business district of Maslak. Additionally, in Derbent, there is a metro station of a line extending to the touristic centre Taksim and then the Yenikap area, which is a big public transportation transfer hub. Below, the Derbent neighbourhood's development history is explained and the most important stages are emphasized (Fig. 2).

The biggest problem in the Derbent district is the conflict between the neighbourhood association and the Atatürk Building Society, which owns the land where the neighbourhood is located. In 1986, the Ataturk Building Society was established, and it bought the land where this gecekondu neighbourhood was constructed. Until that time, Derbent was located on public land and the residents always had the chance to have the right of habitation and make an application for a provisory land title deed. After the purchasing, gecekondu community lost the chance to own the land and they became tenants. Until 20I I, the Atatürk Building Society constructed only MESA houses, which are neighbours of Derbent but the Building Society did not touch the land occupied by Derbent residents. After 2011 , the Building Society made an arrangement with Cemre Construction Agency and they decided to build a luxury-housing site in the Derbent neighbourhood. Cemre Construction Agency started negotiation with
Derbent residents; they visited their houses one by one. 40 gecekondu households agreed to move to mass housing areas and leave their houses to the building agency. This process speeded up the urban transformation rumours in the neighbourhood. Following this process, in January 2013, Istanbul Metropolitan Municipality announced that the Derbent gecekondu neighbourhood was a "risky area". They made this announcement on the basis of a new urban transformation law (6306) describing the construction standards to protect people from earthquake risk. During the design process of the project, no public authority had visited the neighbourhood and no research had been carried out in the area. Even the project for Derbent was introduced by the Mayor of Istanbul at a Real Estate Exposition in Cannes in March 2013, whereas the project aimed to settle a part of the gecekondu residents on site but in a small area separated from the other side. The objectives of the project were listed on the website of Istanbul Metropolitan Municipality on 14 September 2012:

- 600 gecekondu buildings within 800 gecekondu situated on Istanbul Metropolitan Municipality's plot will be relocated to a prefabricated settlement close to the old neighbourhood.

- 1000 houses will be constructed on the site and delivered to the former gecekondu inhabitants.

- A resignation protocol will be signed between the municipality and neighbourhood inhabitants.

- Contractor company will pay all the expenses during the transfer process and will give a commitment letter assuring 50 million TRY.

Table I. Derbent neighbourhood development process

- 1970-1975: Gecekondu houses increase.
1975-1980: Electricity infrastructure established.
- 1980-1985: Provisory Title Deed documents are distributed.
1985-1990: The first bus stop is constructed.
1997: Park Orman is constructed.
- 2002-2005: MESA housing project is constructed.
2009: Acibadem Private Hospital is constructed.
2010: Darrüşafaka Metro Station is established.
2010: Beginning of the Third Bridge rumours
201I: Cemre Construction Agency started negotiation with
Derbent residents
2013: Risky Area Announcement
2013: Derbent Transformation Project in Cannes

7 Derbent is a gecekondu settlement built in solidarity with the residents. First buildings were seen in Derbent in 1937, but the density of the population increased in the 70s. All the infrastructure services were realised by the residents. There are 962 buildings (593 one storey, 1922 storeys, the others have 3-4 storeys). For further details, look at the TUBITAK Project no: I IOK404 report. 


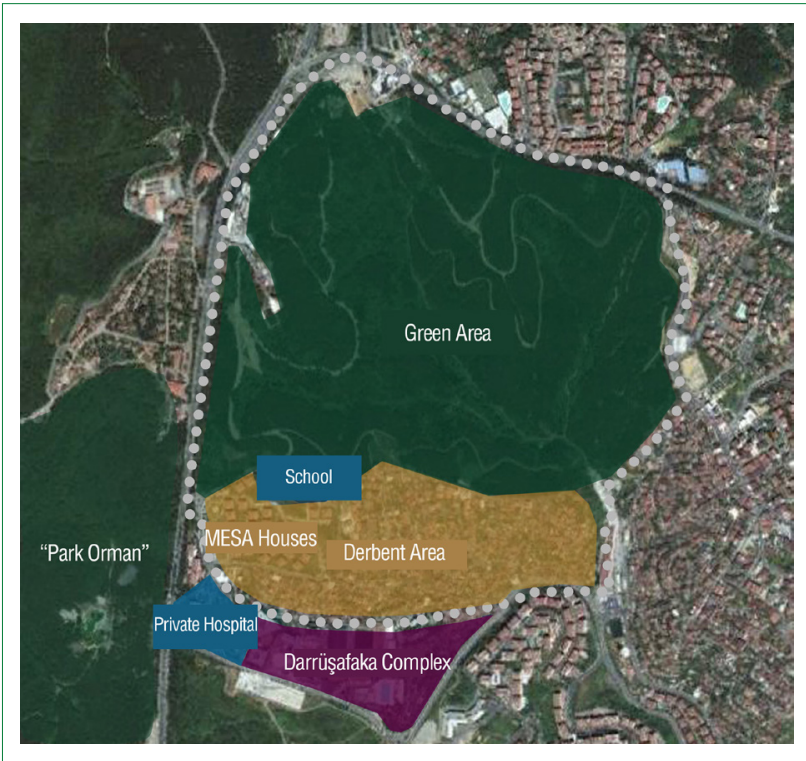

Figure 2. Derbent Neighbourhood.

\section{Right to the "Production of Its Own Space": Choose and Design Its Own Settlement}

Representational spaces are tied to the secret sides of social life. They cannot be conceived concretely but they can be felt (Avar, 2009: 13). Lived space can talk to us much more than representational space. In other words, lived space is the target for architects, planners, investors or other people. They all want to rationalise or occupy this area (Avar, 2009: 13). Lefebvre claims that in to understand space, we need to understand its contradictions and he says (1991: 359) "The contradiction lies, then, in the clash between a consumption of space which produces surplus value and one which produces only enjoyment - and is therefore 'unproductive' It is a clash, in other words, between capitalist 'utilizers' and community "users'".

Community users of our research are Derbent gecekondu residents who chose their neighbourhood and the location of their houses very strategically. This act has material and immaterial dimensions. First of all, they picked a location that was very close to their relatives to develop solidarity relations and enjoyment. They work in proximity of their neighbourhood and they have concrete benefit from this choice. On the other hand they can easily spend time with their friends and family members very often.

$76 \%$ of the participants in the survey claimed that they had family members and relatives in the same neighbourhood and $94 \%$ did not want to leave the neighbourhood. Importantly, social life in neighbourhood usually involves "visiting" the adjacent neighbours or relatives who live nearby. Additionally, due to the location of the neighbourhood, going for a picnic in the forest or on the seashore are among important social activities. We can say that the residents spend their social life mostly around the neighbourhood. Derbent provides them with leisure activities.

"I0-I5 neighbours come and take their cups of tea or coffee, they have a talk, they chat, they have a heart-to-heart talk. This neighbourhood is like a village. We can go to the forest; we can get some fresh air, go for a walk within the neighbourhood... We are like family here." (Kamil, 33, Security Guard)

"If we have a problem, we can call out to our neighbours from the window. We act together and we share our happiness and sadness with each other." (Zeynep, 42, Housewife)

Family conceptualisation is very common in focus groups, explaining feelings about Derbent. A participant uses the term "family-neighbourhood" for Derbent. Family conceptualization creates a warm feeling, shows close relationship among people, but it contains hierarchy and contradictions. Introducing neighbours as family members in focus groups but not as friends opens a new area to discuss the meaning of close relations in neighbourhoods.

In Derbent's case, residents who have single-family houses with gardens use the entire neighbourhood as an extension of their houses. The physical space of the neighbourhood is not separated in strict zones like streets and public spaces, but all the area is used in a very flexible manner. The street is a space for public events. Inhabitants use the street for various activities; it is a socialising space for them. Charmes (2005) declares that even for gentrifying groups, lively streets and close neighbour relations in traditional neighbourhoods are very attractive. In this context, through the middle class, we observe the volition to "go back to the street". On the contrary, low-income groups are sent to mass housing areas and this creates a paradox.

The street is considered very safe and it creates new social relations. Solidarity, festivals and social events take place in the streets. On many occasions, the street is an extension of the house, letting people meet each other (Charmes, 2006: 5-20, 83-I I2). The doorsteps in the neighbourhood are used for washing laundry, storing goods, and spending leisure time, along with many other daily activities. Thus, the sidewalk, street and house appear as elements that complete each other. This may be considered as a factor that increases the satisfaction of the residents in the neighbourhood as many activities that could not be carried out within the house could be carried out in larger spaces such as streets/gardens and in a cooperative way. The importance of the gecekondu neighbourhood and house is vast for its own residents as it is a space that creates social relations and establishes affectivities. Looking from the framework of Lefebvre (1958), it would 
not be possible to think of daily life independent of the space. It may be stated that the opportunities provided by the space and the rhythm of daily life have the likelihood to affect each other, even because of that they are established through interaction with each other. In the focus group meetings, Derbent inhabitants underlined the importance of the streets and the sense of safety in the neighbourhood.

"(MESA inhabitants) don't have places to barbeque; they cannot socialise in the streets. It is a pity." (Kamil, 33, Security Guard)

"On the street, you greet everyone and everyone greets back.” (Mübeccel, 5I, Housewife)

"Doorsteps, gardens and streets are our living spaces; we feel like home here." (Hasibe, 4I, Housewife)

Besides the streets, houses are very important, as is the way these are built in a flexible manner. The flexibility in this neighbourhood may sometimes mean adding a new floor or new room to the building for a married child, sometimes to divide a room for two children. Gecekondu inhabitants can also complete the construction process in 10-20 years and they build when they have sufficient financial resources. Therefore, a gecekondu neighbourhood highly differentiates from a mass housing area, which is built in a top-down process. This important difference was shown in the study about the HLM buildings in France. Sayad (Sayad, 1998, Pp. 103-125), in a monograph that was written about the alienation in social houses in Nanterre, indicates that in shanty towns, the sentiment of belonging is greater than in social houses. Sayad says: "If a shanty town is an 'Arab house', they are built by Arabs for themselves; but the house that is built to replace it is 'a house built for Arabs'. Similarly, Claude Pétonnet (Pétonnet, 1985) claims that the perception of social a solidarity network is very low in groups who are transferred to social housing sites from shanty towns. This distinction is also observed in the case of Derbent.

In our survey, $85 \%$ of the inhabitants were very satisfied with their houses. They renewed the interior design of their house whenever needed and they could add an extra floor or a new room. This construction process let them have a strong sentiment of belonging about their houses.

"In my opinion, (in a house) your soul needs to be comfortable. To stay in a house made by your hand, where you grew up, affects you and your psychology positively. I think it is reflected on my business." (Hasan, 32, Shopkeeper)

On the other hand, young people stated that they need more space in the neighbourhood. They would like to have more educational, cultural and social activity spaces. Countrymen organisations are platforms that are highly oriented towards middle-aged people. Their main aim is to strengthen the contact between the old village and the people coming from there. The neighbourhood association is also very busy with urban transformation issues. We may see that the young people in Derbent are much more urbanised and they choose going to a cinema or having coffee to hang out, and chat with friends. They stated that they need more space to socialise around the neighbourhood in the future.

After all, the Derbent transformation project offers them two solutions; part of the citizens can stay in the same neighbourhood after the new buildings come, but they can only have very small apartments. The rest of the inhabitants have to leave the area, leave their old neighbours and the space they have constructed themselves. Lefebvre (199I) reveals that it is a type of a right not to only occupy a land but also produce an urban space, whereas the project offers only new houses but the construction process is not participative. Designing and building their own houses can also ensure the sentiment of belonging to the house and facilitate that living in it provides all specific needs for that specific household. Having a small garden eliminates the need for an extra room for winter provisions, such as; cracked wheat, sun dried tomatoes or tomato pastes coming from their villages. Children can play in front of the house, and these characteristics might increase the quality of life of the residents. In contrast with the luxurygated communities' residents, gecekondu inhabitants work in their garden and most of them produce vegetables or fruits in their gardens (D. Yücel \& Akı, 20l2). On one hand they enjoy their house and garden, on the other hand they remain the solidarity networks.

\section{Right to the Neighbourhood: Formation and Conservation of Solidarity Networks}

It may be argued that neighbourhood is an important element that creates the feeling of "us" in gecekondu settlements. It provides identity, and balance between internality and externality that contributes to the personality construction of the individual. It prevents becoming an atomised individual while also developing solidarity and a sense of community (Konuk, 201I, pp. 75-82). Neighbourhood is more than a concrete space and it is full of emotions, memories for the inhabitants. They did not have water; they also had neither electricity nor sewers for many years. They obtained these basic needs standing together and they even built the infrastructure together. In this sense, as the questions about the neighbourhood were within the scope of urban transformation, the participants in the focus group meetings or surveys felt it necessary to emphasize their commitment.

We heard concepts such as "inveterate" and "belonging" from many residents of the neighbourhood during the field 
study. Issues such as living one's childhood in this neighbourhood, growing up in the neighbourhood, being familiar with most of the residents or being like brothers were the most emphasised issues.

The neighbourhood means two important things for the gecekondu community living in Derbent. Firstly, communities living in Derbent feel at home in the neighbourhood and their place attachment is high. Secondly, the solidarity networks are important, create a strong sentiment of belonging to neighbourhoods and help people make everyday life easier.

This situation can be explained by that they have been living in this neighbourhood for a long time, they have built the neighbourhood together and feel at home there. $68 \%$ of the participants in the survey conducted in the Derbent neighbourhood had been living there for more than 20 years. At the same time, the fear that possibility of urban transformation would affect these values could be felt during the interviews. This was also seen in that almost every issue was somehow related to the sentence "we do not want to leave the neighbourhood." $96 \%$ of the participants said they were happy to live here and $94 \%$ said they would not agree to leave the neighbourhood. Knowing a couple of hundred people in the neighbourhood or being like brothers were important points we observed during the surveys.

The feeling of trust that rose through solidarity practices in the space is important especially for women. This factor helps women to acclimatise to the space. The words of a woman from the Derbent neighbourhood mentioned both points:

"To enter the Derbent neighbourhood is like entering your own house. I feel safe here." (Ayşe, 32, Babysitter)

Especially young and unmarried women had concerns about close neighbourhood relations. They revealed that they need to watch out their behaviour in the neighbourhood. On one hand, having close relationships makes the residents feel safe, but one the other hand, it increases conservatism.

The solidarity relationships in the neighbourhood contribute to overcoming the dominance of organisations and allow unity among the residents to spread around the neighbourhood. The story told by an executive board member of the Derbent neighbourhood association during the interview was striking:

"Here in Derbent, every building has been built by the Imece method. ${ }^{8}$ All people helped each other build the houses. The children of that time grew up and now they are 30-40 years old. They have close relations with each other like their fathers or mothers. I don't want any other kind of building here." (Executive member of the neighbourhood association, male, 46.)

About $80 \%$ of the participants said that they would prefer not to be separated from their neighbours if they had to leave the neighbourhood. This was especially true for youths as individuals who were born and grew up in the neighbourhood as more socialised individuals. Some field studies determined that neighbourhood, as a space, is a source of identity almost equal to the root identity for youths during socialisation processes in the case of unauthorised neighbourhoods (H. Yücel, 2005).

The interviews we conducted with youths indicated that even though there are some needs in the neighbourhoods, they do not accept urban transformation and are against leaving the neighbourhood because:

"If the neighbours are going to be kept together - if it continues as we are now, next to each other, I would like to stay in a comfortable house." (Housewife, 24)

The feeling of spatial attachment and residency of the same neighbourhood are being transformed by the threats of urban transformation. It was observed that the neighbourhoods pressurised by big investments, shopping malls and closed sites turn out to be more inward-oriented and adhere to solidarity relations, although envying the life style of the wealthy at certain points. As the youth question why their neighbourhoods do not have the same social opportunities as the ones in wealthy closed sites, or as the residents of those wealthy sites could easily come and shop in their neighbourhood, the fact that the access of residents in unauthorised neighbourhoods is restricted to those places probably indicates the core of social polarization. Therefore, we may clearly state that gated community developments through urban transformation have become huge urban problems with their polarizing, segregating and non-communicative characteristics. $60 \%$ of the survey participants were very disturbed by the security walls of the gated communities. They claimed many times that they felt "stuck" because of the walls.

"Gated communities were built and then we (women) thought that we could find jobs there. But some time later, we were tucked here. Everybody considers us occupiers; our houses are accepted as garbage. If they build something good around us, it brings us harmful things." (Ayşe, 32, Babysitter)

"... the walls of MESA build segregation like the Berlin Wall and this makes me very unhappy." (Mehmet, 46, Executive)

While the sentiment of belonging becomes stronger after 
the urban transformation threat, new projects bring a bad feeling about their environment, and additionally break the sentiment of belonging. Segregation starts between luxury sites and gecekondu housing areas. This segregation disturbs gecekondu inhabitants and creates feeling of exclusion.

Solidarity relationships are as important as the commitment to the neighbourhood and home/street. The past and current life style in neighbourhoods is always explained by putting solidarity relationships at the centre. The majority of the residents who mentioned their concerns and suspicions about urban transformation mostly emphasized daily life relationships. Within this context, the most frequently discussed subjects in focus group meetings were that usage of streets and gardens would not stay the same if urban transformation was realised and this would affect the relationships in a bad way.

"The design of the new project is not that important. The size of the house is more important. Here, people have a single-floor gecekondu, but they have a large garden and they use it." (Hüseyin, 29, works at a company)

The solidarity practices have been going on since the establishment of the neighbourhood. These practices have both strengthened the commitment of residents towards each other and eased life, thereby turning this place into a space that is identified with.

The surveys and interviews conducted with youths, middle-aged men and women revealed that the residents of the neighbourhood have a lot of acquaintances from the neighbourhood. In particular, women stated that knowing each other was a great advantage that eased life. $62 \%$ of the survey participants indicated that they recognise 50 or more households in the neighbourhood. In addition to this, the people who would go and ask help from their neighbours whenever they have a problem constituted the majority. This indicates that the highest rate of trust within the neighbourhood is not towards the state or its institutions, but towards each other. More than half of the interviewees said that they have acted together in participating in weddings or funerals, shopping, or housework, which representthe living habits in neighbourhoods. Young women declared that they were not able to have coffee with their boyfriends in the neighbourhood. They were not even able to walk in the neighbourhood with a close friend from the opposite sex. Besides, they stated that conservative reactions are diminishing day by day. On the other hand, young people reported that they are very mobile thanks to the metro and minibus lines. They could go to Taksim, Beşiktaş and Maslak to meet their friends, go to the cinema.

The rate of preparing winter supplies with the neighbours was high (57\%), and this gives us some hints about the spatial organisation and social solidarity within the neighbourhoods along with daily life practices. Preparation of winter supplies is the process where women prepare the food they will use throughout the winter in accordance with collective work by using supplies coming from their villages. There is spatial organisation, which is necessary for these preparations, and the place for preparation may be a garden, veranda, terrace and even the street. In this sense, preparing winter supplies together does not only mean solidarity, on the contrary a new space is created outside the "house".

The most striking fact from the survey in the neighbourhood was the continuation of on-account shopping. Almost $83 \%$ of the respondents mentioned that they could still buy things from the neighbourhood market and pay later.

In this sense, solidarity in the neighbourhood appears under two titles: economic and social. Making on-account purchases from the neighbourhood market, in a sense, makes it possible to delay the necessity to have a permanent job for a certain period. This economic solidarity is a must as a response to the current capitalist circumstances, but it also indicates the possibility of a local economy. Below, you can see the survey results showing the economical solidarity in the neighbourhood.

- I borrow from my neighbour if necessary. $81 \%$

- I can make on-account purchases from the neighbourhood market. $82.8 \%$

- My neighbour looks after my child. $87.46 \%$

- When I get into trouble, I call my neighbour first. $89.61 \%$

Solidarity networks can also meet people's material and immaterial needs together. Living close to relatives or trusting a neighbour can provide financial benefits because one does not spend money for child-care, house work, reparation works. Additionally, this may cause an ambiance of confidence, thus strengthen the sentiment of belonging.

\section{Right to Self-Government: Institutionalisation of Solidarity Networks}

Alongside solidarity in daily life, by the popular use of the term, creation of unauthorised neighbourhoods could be read as the product of an urban social movement. The residents of unauthorised neighbourhoods have created their own living spaces without the support of the state, the local administration or any other public authority. Purcell (2002, p. 105) emphasizes that the concept of the right to the city is a call for need of a new urban politics. In gecekondu neighbourhoods, we encounter new ways to organise and turn informal solidarity actions into an institutionalised movement. 
There are many researchers who define creation of these informal settlements as "social movements". Within this context, Bayat used the concept of "street politics" in order to indicate and explain how the gecekondu areas in Iran have developed without a certain ideology and a certain leader, and how the owners of these gecekondu settlements have silently opposed the existing system, and named the action itself as "quiet encroachment" (Bayat, 2008). Within this context, according to Bayat, usage of the street in an active and participatory way without the control of the state is a type of urban movement (lbid: 45). Bayat defines the concept of "street politics" in unauthorised neighbourhoods as "the silent, patient, long term and consistent walk of the average people on property owners and the wealthy, in order to overcome their problems and live a better life (lbid: 35 ).

The change of action practices are observed, and urban transformation practices have been carried out through the means of private contractors after the year 2000 in the neighbourhoods of Sariyer, where the politics of the street are executed by associations and cooperatives and organisational forms.

Since its creation, most urban services that neighbourhood residents required were realised by solidarity practices and with cooperation, and the problem of "property" was considered as an important agenda in these neighbourhoods as in authorised ones. In particular, planning amnesty and "individual deed" have been considered as the sole legal assurance and the warrant to stay in these neighbourhoods since 1980s. Even though there are several countryman associations, thought associations or cultural associations in neighbourhoods, we observed that the neighbourhood association has a neutral stance and it could take the form of an important tool to create a comprehensive organisational identity that is mobilised only from living within that neighbourhood. Among the respondents, membership of countryman associations was around $27 \%$, while the rate of membership for neighbourhood associations was $37 \%$. The neighbourhood association was a more overarching organisation among the neighbourhood residents. This association is also a part of the "Neighbourhood Associations Platform of Sarıyer". This platform has monthly meetings, the members of the platform share information with all residents without any distinction between members or non-members. Derbent neighbourhood association members do not only work against the urban transformation process but they are also trying to resolve everyday life problems. Music lessons, math lessons or coaching classes for the university entrance examination for young people are very popular activities organised by the neighbourhood association. On the other hand, the neighbourhood association does not work like "not in my backyard" organisations. Association members have cooperation with other neighbourhood associations and they even work with opposition groups in Istanbul like the "Northern Forests Defence Platform" or "No to the $3^{\text {rd }}$ Bridge Platform", 9 while universities also work in the neighbourhood together with the neighbourhood association. The most important example is the solidarity of Derbent neighbourhood association with the Gezi Park movement $^{10}$ in $2013^{11}$.

Self-government activities in Derbent came up to the next level with the establishment of the cooperative to resolve the ownership problem. The cooperative structure is a brandnew concept for gecekondu neighbourhoods, even though cooperatives go far back in Turkey's history. Especially in the Sarıyer district, we had many gecekondu neighbourhood cooperatives working together, interacting with each other. We observed that their establishment declaration documents are alike; they were observed to be working democratically to have the land as property. They are not informal groups, and all their actions are based on legal documents.

The case of Derbent is specific in some points. First of all, Istanbul Metropolitan Municipality owns the majority of the land in the Derbent neighbourhood. According to the "Gecekondu Law (No. 775)" gecekondu residents can apply to have the property of the land on which they built their houses and if it is public property, dwellers have the right to have a "provisory title deed". This document can become a permanent title deed if a "development plan" is prepared according to the urban amnesty law (No. 298I). In the case of Derbent, the development plan is not made yet. In addition to this, the plot owned by the municipality was sold to a building society. The aim of the cooperative is to stake out a claim on the land they have been residing on for more than fifty years. This cooperative has a founding declaration clarifying their democratic decision-making processes. The first rule is that the board of management cannot decide by simple majority of votes, and they need to obey the consultative committee comprising $20 \%$ of the members. Their aim is to have the land without any cost and they try to have a collective ownership ensured by this cooperative structure.

In 2016, the board of management of the cooperative negotiated with Sarıyer Municipality to realise the development

9 Kuzey Ormanları Savunması Platformu, 3. Köprüye Hayır Platformu

10 The Gezi Park movement is an opposition movement that occurred in Taksim, Istanbul. Istanbul Metropolitan Municipality decided to build a shopping mall in Taksim Gezi Park but the people resisted the decision and they wanted the Gezi to stay as a green area. An occupy movement began and thousands of people came to Gezi Park to protest the Municipality. For further details: Aksümer G and Ezme AT. (2015) Desire Flows in Gezi Park. 20. International Conference on Alternative Futures and Popular Protest (30 March - Ist April 20I5). Manchester Metropolitan University.

II Neighbourhoods Searching for Justice (This is a Gecekondu neighbourhood associations platform and Derbent Neighbourhood Association is a part of this organisation) organised a march to Gezi Park in 2013 when the Gezi Park movement took place in Taksim, Istanbul. Further details: https://kentteadaletblog.wordpress.com/20I3/06/I0/ adalet-arayan-mahalleler-gezi-parkina-yurudu/ 
of the urban master plan and transfer the land to the cooperative. They have weekly meetings with the consultative committee, cooperate with professionals, have seminars and listen to recommendations. In July 2017, improvement plans (Islah planı) of the Derbent neighbourhood were sent to Istanbul Metropolitan Municipality for approval. After the planning process, they will continue to spend efforts for having legal assurance for their houses.

We might consider this initiative as a big step towards more democratic urban governance and a straight path to the right to the city.

\section{Conclusion: Immaterial Dimensions of the Right to the City}

A city is created by social relations. As Lefebvre stated (1968, p. 47), we cannot understand the urban issue as the material city, but we need to know the senses, spontaneous exchanges and relationships among people. In our case study, social relationships are so important that even the design of the neighbourhood and the location of the settlement is also irreplaceable. Lefebvre (1991: 85) said that the space is a product of social relations and the space of Derbent is rather a social network constituted by its inhabitants.

In the case of Derbent, we see two aspects of the phenomenon. On one side, we observe daily lives and habits, and we discover that solidarity networks are still crucial for their capacity of keeping the urban environment. On the other side, we see an urban transformation project that aims to build a new housing area, claiming to renovate the neighbourhood, but we observe that this project creates two groups of big blocks of buildings, separating the Derbent community by walls from upper-middle income groups. This segregation disturbs the inhabitants of Derbent. Furthermore, it decreases their space, removes gardens, and carries them to high-rise buildings. This change most likely has the capacity to entirely change the daily life of the Derbent community. They are really sensitive about gated communities and they do not want to be surrounded by walls. Young residents are particularly very sensitive about luxury housing areas separated from others. In the case of MESA and Derbent, we can see the tension among younger people. Social relations here become conflicting and the design of the space increases the conflict between different social groups.

In Derbent's case, the neighbourhood and the daily life constituted there, is the centre of economic and social solidarity. Spatial belonging and attachment to the neighbourhood have high importance for the residents. People refer to their memories of solidarity actions, talk about how they built the neighbourhood, and underline the close relationships they have in the neighbourhood. The most interesting part of the study was that even the young inhabitants want to keep solidarity relations among each other. Moreover, they emphasized the importance of the physical space of their neighbourhood; gardens and streets which are used for public events are crucial for their daily life. Derbent is built by solidarity networks and the design of the neighbourhood is also very important. They look after their neighbour's children, they can borrow money from their neighbour and when they get into trouble they call their neighbour first.

To define the right to the city in the case of Derbent, we cannot only mention economic issues, or we cannot only discuss the housing right of gecekondu community. This right may be defined in three dimensions in the case of Derbent. First of all, Derbent inhabitants built the space on their own and they want to conserve their physical space, and even if it is necessary to make any renovation, they emphasize that they need to have agency in this project. Their future visions indicate that they want the right to the production of their own space. Not changing the location of their house is a common expectation for young and middle-aged residents, men and women. They all reveal that the organisation of locations in the neighbourhood is very important for them and the centrality of their houses (close to metro station or business district) makes them feel more attached to the area. Gardens are very important, and they do not want to leave their green areas. Secondly, they clearly claimed that they want to continue their social relations and live together with their old neighbours. Old and young people stated that they have close friends and neighbours in Derbent, and they feel safe there. Women, especially young and unmarried women have some concerns about close neighbourhood relations; even if they feel very safe most of the time, they stated that they need to watch their behaviour in the neighbourhood. Young residents reported that they often went out with their friends. Increasing mobility capacity of the residents allows them to have another life outside the neighbourhood whenever they want. For the future, young people would like to have more social spaces, cafes, or restaurants around the neighbourhood to hang out with friends. They also would like to have sportive, cultural and educational activities.

Thirdly and most importantly, they started to build a cooperative, which lets us see how alternative urban politics can be established from down to top. Another important expectation was their involvement in the planning process of their neighbourhood. First of all, they need legal assurance for their own land and house. After that, they claimed that they needed some physical changes in their neighbourhood if and only if they become a part of the planning process from the very beginning. 
As opposed to a single, large-scaled and abstractly defined concept, the right to the city has multiple meanings. On one side, it may be defined as a kind of the right to selfgovernment, while on the other side, it is a right to protect the immaterial city which includes social relations and the relationship with the built environment. Lefebvre (1996: 158) states that the right to the city can be formulated as a renewed right to urban life. The inhabitants of Derbent emphasize that they are attached to their neighbourhood and "they scream for the right to the city".

This study shows that the concept of the right to the city must be indispensable for urban renewal or transformation projects. This right must be used to conserve the social relations that all the citizens would like to conserve and create the future all citizens would like to have.

This urban transformation style can never aim to meet the needs of the inhabitants or the needs of the metropolitan city of Istanbul. This is an urban project, which is focused on material needs, and it reduces the inhabitants' right to the city solely to their housing right. The urban transformation process in the Derbent gecekondu area shows that the concerns are not only about a "building", but also about having a "home" and the inhabitants do not want to leave all their social relations and their "home". This demand matches with Harvey's (2012: 4) claim about the right to the city: "The right to the city is, therefore, far more than a right of individual or group access to the resources that the city embodies: it is a right to change and reinvent the city more after our hearts' desire."

\section{REFERENCES}

Albarello, L. (2007). Apprendre À Chercher, Lacteur Social et la Recherche Scientifique. Paris: De Boeck \& Larcier.

Attoh, K. (2011). What kind of right is the right to the city? Progress in Human Geography, 35(5), 669-685.

Avar, A. A. (2009). Lefebvréin Üçlü - Algılanan, Tasarlanan, Yaşanan MekânDiyalektiği. Mimarlık Dergisi, Aralık, 7-17.

Balzarini, J. S., Anne;. (2015). Gentrification and the Right to rhe City: Community Conflict and Casinos. Journal of Urban Affairs, 00(0), 1-15.

Bayat, A. (2008). Sokak Siyaseti: İran'da Yoksul Halk Hareketleri S. Torlak (Trs), . Ankara: Phoenix Yayınları.

Zizek, S. (2009). Matrix: Ya da Sapkınlığın İki Yüzü. Bahadır Turan (Trs.).

İstanbul: Encore.

Bayat, A. (2010). Life as Politics: How Ordinary People Change the Middle East. Amsterdam: Amsterdam University Press.

Baysal, C. (2011). Kent Hakkı Yeniden Hayat Bulurken. Eğitim Bilim Toplum, 9(36), 31-55.

Buds, J., \& Teixeira, P. (2005). Ensuring the Right to the City: Pro-poor housing, urban development and tenure legalization in São Paulo, Brazil. Environment and Urbanization, 17(1). 89-113

Charmes, E. (2005). Le Retour À La Rue Comme Support De La Gentirifcation. Espaces Et Sociétés, 122, 115-135.

Davis, D., Moore, N., Wright, M., \& Zykofsky, P. (2013). Participation Tools for Better Community Planning. Sacramento: Local Government Commission.

Davis, M. (2006). Planet of Slums. London - Newyork: Verso Publication.

De Souza, M. L. (2011). Hangi Kentte Hangi Hak? Politik-Stratejik Netliğin Müdaafası. Education Science Society Journal, 9(36). 183-207.

Friedmann, J. D., M; (Ed.). (1998). Cities for Citizens: Planning and the Rise of Civil Society in a Global Age. New York: Wiley.

Gönen, Z. (2008). Varoşların Zabtiyesi ya da Kent Yoksullarının Neoliberal Denetimi. ToplumBilim, 23, 93-103.

Harvey, D. (2000). Spaces of hope. Berkeley Los Angeles: University of California Press.

Harvey, D. (2008). Right To The City. New Left Review, 53(September-October). Retrieved from New Left Review website: http://newleftreview. org/II/53/david-harvey-the-right-to-the-city

Harvey, D. (2012). Rebel Cities: From the Right to the City to Urban Revolution. London: Verso Pub.

Konuk, M. (2011). Mahalle: Bir Kimlikler Kavşağı. Toplum Bilim, 26(Nisan 2011), 75-82

Kurtulus, H., \& Turkun, A. (2005). Giriş. In H. Kurtuluş (Ed.), İstanbul'da Kentsel Ayrışma: Mekânsal Dönüşümde Farklı Boyutlar. İstanbul: Bağlam Yayınları

Kuyucu, T. Ü., Özlem;. (2010). Urban Transformation as State Led Property Transfer: An Analyses of Two Cases of Urban Renewal in Istanbul. Urban Studies, 47(7), 1479-1499.

Langegger, S. K., Stephen;. (2016). Invisible homelessness: anonymity, exposure, and the right to the city. Urban Geography, 37(7), 1030 - 1048.

Lefebvre, H. (1958). Critique de la vie quotidienne 1 Introduction (2nd ed.). Paris: l'Arche.

Lefebvre, H. (1968). La vie quotidienne dans le monde moderne. Paris: Gallimard.

Lefebvre, H. (1991). Production of Space. Oxford: Blackwell Publication. D. Nicholson-Smith (Trs.). (1st ed. 1974)

Lefebvre, H. (1996). Writings On Cities. Oxford: Blackwell Publication. E. Kofman, E. Lebas (Trs.). (1st ed. 1996)

Marcuse, P. (2012). From Critical Urban Theory to the Right to the City. In N. Brenner, Peter Marcuse, and Margit Mayer (Ed.), Cities for People, Not for Profit: Critical Urban Theory and the Right to the City. New York: Routledge

Masuda, J. B., Sonia;. (2016). Neighbourhood branding and the right to the city. Progress in Human Geography, 1-18.

Mayer, M. (2011). Kentsel Toplumsal Hareketlerde Kent Hakk1. Eğitim Bilim Toplum, 9(6). 153-182. 
McCann, E. (2002). Space, Citizenship and the Right to the City: A Brief Overview. GeoJournal, 58.77-79.

Mitchell, D. (2003). The Right to the City. New York: Guilford Publications.

Pérouse, J. F., \& Danış, D. (2005). La Politique Migratoire Turque: Vers Une Normalisation? Migrations Société, 17(98).

Pétonnet, C. (1985). On Est Tous Dans Le Brouillard. Paris: Editions Gallilée.

Pierce, J., Williams, O., \& Martin, D. (2016). Rights in places: An analytical extension of the right to the city. Geoforum, 70, 79-88.

Purcell, M. (2002). Excavating Lefebvre: Right to the city and its urban politics of the Inhabitant. GeoJournal, 58(2/3).

Purcell, M. (2003). Citizenship and the Right to the Global City: Reimagining the Capitalist World Order. International Journal of Urban and Regional Research, 27(3), 564-590.

Sayad, A. (1998). Un Nanterre Algérien, Terre de Bidonvilles. Paris: Autrement.

Sen;, B., \& Doğan, A. E. (2010). Neoliberalizm Mekânı ve Mücadele Deneyimleri Tarih, Sinıflar ve Kent. İstanbul: Dipnot Yayınları

Şen, B. (2006). Kentsel Gerilemeyi Aşmada Çelişkili Bir Süreç Olarak Soylulaştırma: Galta Örneği. (Doktora), Mimar Sinan Güzel Sanatlar Üniversitesi, İstanbul

Yalçıntan, M. C., Çılgın, K., \& Çalışkan, Ç. (2012). İstanbul Dönüşüm Coğrafyası 3. Kentsel ve Bölgesel Araştırmalar Sempozyumu (Kent, Bölgeler, Metropoliten Alanlar, Büyükşehirler: Değișen Dinamikler ve Sorunlar). 294-312. Ankara: Kentsel ve Bölgesel Araştırmalar Ağ1

Yücel, D., \& Akı, M. (2012). Kentsel Politik Ekoloji Bağlamında Farklı Doğa Tahayyüllerinde Sosyo-Ekolojik İlişkiler: Gecekondu Mahallesi-Kapalı Site Karşılaştırması. In A. D. E. Mim Sertaç Tümtaş, Cem Ergun (Ed.), Kente Dair. İstanbul: Bağlam Yayınları

Yücel, H. (2005). Les jeunes alévis du quartier de Gazi (Istanbul) et les associations de hemșehri : identifications croisées. European Journal of Turkish Studies, Hometown Organisations. URL: http://journals.openedition. org/ejts/406 